\title{
Effect of Azolla (Azolla pinnata) Supplementation on Milk Yield, Composition and Economics in Crossbred HF Cows
}

\author{
Manpreet Kour*, Nazam Khan, Rajeev Singh, Vikas Mahajan, \\ Suraj A. Amrutkar and Dhirendra Kumar ${ }^{1}$
}

Division of ILFC, Division AGB, FVSc \& AH, SKUAST-Jammu, R S Pura, India

*Corresponding author

\section{Keywords \\ Azolla, Crossbred cows, Milk yield, Milk composition \\ Article Info \\ Accepted: \\ 20 September 2020 \\ Available Online: \\ 10 October 2020}

\section{A B S T R A C T}

An experiment was conducted on ten crossbred cows $\left(400 \pm 25 \mathrm{~kg}, 3^{\text {rd }}\right.$ to $4^{\text {th }}$ lactation) for sixty days to study the effect of azolla supplementation on milk yield, composition and economics in crossbred cows during September- October 2016. The animals were randomly divided into two groups on the basis of average milk production $(6.77 \pm 0.35$ $\mathrm{kg} /$ day; $\mathrm{n}=5$ ). Basal ration was same for both the groups except fresh azolla supplementation@ 500/g/day in treatment group. The results revealed significantly higher $(\mathrm{P}<0.05)$ mean milk yield in treatment group $(8.30 \pm 0.41 \mathrm{~kg} /$ day $)$ in comparison to control $(7.17 \pm 0.53 \mathrm{~kg} /$ day $)$. However no beneficial effect of azolla supplementation was observed in milk composition i.e. milk fat, milk protein and SNF, whereas, milk fat yield was found significantly higher $(\mathrm{P}<0.05)$ in treatment group $(0.33 \mathrm{~kg} / \mathrm{day})$ in comparison to control $(0.28 \mathrm{~kg} /$ day $)$. Also, the benefit cost ratio was found higher in treatment group (1.01) than control (0.73). On the basis of results, it is concluded that azolla supplementation in feeding regimen of crossbred cows is beneficial which is evident by increased milk yield, milk fat yield and improved benefit cost ratio.

\section{Introduction}

Livestock production is an important aspect of Indian economy and has been a major source of employment generation especially for rural areas. There is huge gap between demand and supply of feed and fodder in India (Chatterjee et al., 2013), which can be bridged to some extent by exploring unconventional feed resources as supplement or replacement of conventional feed. One of the promising alternatives is Azolla, a free floating aquatic fern, which under ideal conditions grows exponentially, doubles its biomass in every three days. It is synonymously called Green gold mine due to its high nutritive value and Super plant due to its fast growth.

Azolla hosts symbiotic blue green algae, Anabaena azollae, which is responsible for the fixation and assimilation of atmospheric nitrogen. In turn, it provides the carbon source and favorable environment for the growth and development of the algae. It is this unique symbiotic relationship that makes azolla, a 
wonderful plant with high protein content. There are at least eight speciesof Azolla worldwide; Azolla caroliniana, Azolla circinata, Azolla japonica, Azolla mexicana, Azolla microphylla, Azolla nilotica, Azolla pinnata and Azolla rubra. But Azolla piñnata is commonly found in India. Its protein is 4 to 5 times better than lucerne and hybrid napier. Besides this, its bio- mass production is almost 4 to 10times than hybrid napier andlucerne, respectively (Senthilkumar and Manivannan, 2016). It can be produced in pits or can be cultivated from stagnant water of river, canal, pond etc (Chatterjee et al., 2013). But its cultivation from nearby factories/industries should be avoided as it can be polluted with heavy metals.

Azolla has $25-35 \%$ protein content, $10-15 \%$ mineral content, and $7-10 \%$ combination of amino acids, bio-active substances and biopolymers on dry matter basis (Kamalasanana et al., 2002). It is also rich in iron (1000-8600 ppm on dry weight basis), copper (3-210 ppm dry weight) manganese (120-2700 ppm dry weight), vitamin A (300600 ppm dry weight), vitamin A (300-600 ppm dry weight), chlorophyll and carotenes. It contains $4.8-6.7 \%$ dry weight crude fat, with $6.1-7.7 \%$ and $12.8-26.4 \%$ total fat for the polyunsaturated fatty acids omega 3 and omega 6, respectively. In addition, it does not accumulate plant secondary compounds and therefore has a greater potential as protein source for monogastric animals also (Singh et al., 2017). Around one hectare of azolla can produce $540-720 \mathrm{~kg}$ of protein per month. It has been reported as one of the most economic and efficient feed substitutes for livestock, particularly as can be easily digested by livestock due to its high protein and low lignin content.

Earlier researchers too documented its potential as livestock feed in dairy animals (Singh et al., 2017: Mathuer et al, 2013,
Chatterjee et al., 2013), pigs (Kamalasanana et al., 2002, Alvaro OcampoDurán, 1994) and poultry (Kamalasanana et al., 2002, Mahadevappa et al., 2012, Alalade and Lyayi 2006)). Keeping in view the above facts, present study was undertaken to evaluate the effect of azolla supplementation on milk yield, its composition and economics in crossbred HF cows.

\section{Materials and Methods}

The present study was conducted on ten lactating crossbred $\mathrm{HF}$ cows $\left(3^{\text {rd }}\right.$ to $4^{\text {th }}$ lactation), randomly divided in two groups $(n=5)$ on the basis of mean body weight $(400 \pm 25 \mathrm{~kg})$ and average milk production $(6.77 \pm 0.35 \mathrm{~kg} /$ day $)$ to evaluate the effect of azolla supplementation on milk yield and composition on September and October 2016.All the animals were housed at dairy farm, ILFC, FVSc \& AH, SKUAST-J, RSPura. All the standard protocols of deworming and vaccination were followed.

The control group (C) was fed with chaffed green fodder (mixed maize fodder and sorghum), paddy straw and concentrate, whereas in treatment group (T), in addition to basal ration, fresh azolla was supplemented@ $500 \mathrm{~g} / \mathrm{animal} / \mathrm{day}$. All the animals have free access to drinking water thrice daily.

The chemical composition of paddy straw, concentrate and azolla on dry matter basis is presented in Table 1 whereas the ingredient composition of concentrate mixture is presented in Table 2. Concentrate mixture was offered in two proportions at milking time. Whereas, chaffed green fodder was fed singly at 11 a.m. But adlib paddy straw was offered throughout the day. The feeding trial lasted for sixty days from September to October 2016. During the trial daily milk yield was recorded (animals were hand milked twice at 06:30 a.m. and 05:00 p.m. 
whereas milk composition was analyzed at 20 days interval by using automatic milk analyzer (Lactostar). The feed samples were analysed for proximate composition (AOAC, 2005) and fibre fractions (Van Soest et al., 1991)

\section{Cultivation and Harvesting of Azolla}

An artificial water body was made under shade of the tree. This pit is then covered with plastic gunny bags to prevent the growth of roots of nearby trees and to protect the seepage of water. Over these plastic gunny bags, plastic sheet (tarpal) is spread without any folds. The size of the plastic sheet was $0.5 \mathrm{~m}$ longer and wider than the pit and was secured by a layer of mud at the edges. About $10-15 \mathrm{~kg}$ of soil was sieved, which is than mixed with $5 \mathrm{~kg}$ of cow dung.

Above mixture of soil and cowdung was made into slurry by using 10 liters of water and was uniformly spread over the plastic sheet covering the pit. After that the water was poured in to the pit to make the water level at about $8 \mathrm{~cm}$. About $1-2 \mathrm{~kg}$ of fresh healthy azolla seed culture was inoculated in the pit. Within 7-10 days, azolla filled the pit and about 1-1.5 kg of Azolla was harvested daily thereafter. To keep the growth of azolla in rapid multiplication phase, about $1 \mathrm{~kg}$ of sieved soil and $1 \mathrm{~kg}$ of cow dung was made into slurry in 2 liters of water and poured in to the pitat 10 days interval as per need. Azolla was harvested by using plastic sieves, washed and then stored in unused mengers of dairy shed having $1 \mathrm{~cm}$ water level. Following this methodology, about $1.5 \mathrm{~kg}$ fresh azolla was collected daily for feeding treatment animals @ $500 \mathrm{~g} /$ day/animal by mixing concentrate. The economics in terms of net return and benefit cost ratio (B:C ratio) was also estimated.

\section{Statistical analysis}

The data obtained in the present study was analysed by using two way ANOVA as described by Snedecor and Cochran (1989). The test of significance among the different treatments was also analysed (SPSS, 1999).

\section{Results and Discussion}

\section{Effect of azolla on milk yield}

The results revealed that crude protein content (\%) of azolla is comparable to concentrate mixture formulated in the present study (Table 1). No effect of azolla supplementation on milk yield ( $\mathrm{kg} /$ day) was observed up to $20^{\text {th }}$ day, This might be because of unacclimatization of rumen microbes to utilize azolla properly but afterwards milk yield was significantly improved $(\mathrm{P}<0.05)$ in treatment group (8.95, 9.40 at 40 and 60 days, respectively) in comparison to control (7.29, 7.93 at 40 and 60 days, respectively; Table 3). The average milk yield of the entire trial was found significantly higher $(\mathrm{P}<0.05)$ in azolla supplemented group $(8.30 \mathrm{~kg} /$ day $)$ than control $(7.17 \mathrm{~kg} /$ day $)$. The increase in milk yield might be due to extra nutrients supplemented through azolla feeding. These results are in line with the findings of Gouri et al., (2012), Ambade et al., (2010), Rawat et al., (2015) and Gowda et al., (2015), who too reported that azolla supplementation has beneficial effect in increasing milk yield

\section{Effect of azolla on milk composition}

The effect of azolla supplementation on milk composition (\%) of crossbred HF cows is presented in Table 4. Different milk components viz. milk fat, milk protein, milk lactose and milk SNF were statistically similar irrespective of different dietary treatment, but interesting all the values were numerically higher in treatment group. However average milk fat (kg/day) was 
significantly higher in treatment group than control $(0.33 \mathrm{~kg} /$ day Vs. $0.28 \mathrm{~kg} /$ day in treatment and control group). Similar trend was observed at $40^{\text {th }}$ and $60^{\text {th }}$ day of trial with respect to milk fat yield (kg/day). Average milk protein $(\mathrm{kg} /$ day), milk lactose ( $\mathrm{kg} /$ day) and milk SNF (kg/day) were not influenced by dietary supplementation of azolla, but the values were numerically better in treatment group than control. Higher milk constituents (\%) and higher milk yield in azolla supplemented group might be the probable reason for increased milk constituent yield $(\mathrm{kg} / \mathrm{day})$ in azolla supplemented group (Table 5).

Table.1 Chemical composition of paddy straw, concentrate and azolla (on \% DMB)

\begin{tabular}{|l|c|c|c|c|c|}
\hline Ingredient & $\begin{array}{c}\text { Crude protein } \\
(\mathbf{\%})\end{array}$ & $\begin{array}{c}\text { Ether extract } \\
(\mathbf{\%})\end{array}$ & $\begin{array}{c}\text { Total ash } \\
(\mathbf{\%})\end{array}$ & $\begin{array}{c}\text { Neutral detergent } \\
\text { fibre (\%) }\end{array}$ & $\begin{array}{c}\text { Acid } \\
\text { Detergent fibre (\%) }\end{array}$ \\
\hline Paddy straw & 2.91 & 0.99 & 12.11 & 64.20 & 5.29 \\
\hline Concentrate & 21.22 & 4.10 & 7.18 & 32.19 & 16.33 \\
\hline Azolla & 21.04 & 2.70 & 16.1 & 60.11 & 34.80 \\
\hline
\end{tabular}

Table.2 Ingredient composition of concentrate mixture

\begin{tabular}{|l|l|}
\hline Ingredient & Parts $(\boldsymbol{\%})$ \\
\hline Crushed maize & 18 \\
\hline Crushed barley & 25 \\
\hline Wheat bran & 15 \\
\hline Rice polish & 5 \\
\hline Chilka & 5 \\
\hline Mustard cake & 29 \\
\hline Mineral mixture & 2 \\
\hline Salt & 1 \\
\hline
\end{tabular}

Table.3 Effect of azolla supplementation on milk yield (kg/day) and economics of crossbred HF cows

\begin{tabular}{|l|l|l|l|l|l|l|}
\hline & \multicolumn{2}{|c|}{ Milk yield (kg/day) } & \multicolumn{2}{c|}{ Net returns } & \multicolumn{2}{c|}{ Benefit: cost ratio } \\
\hline Days & Control & Treatment & Control & Treatment & Control & Treatment \\
\hline $\mathbf{0}$ & $6.60 \pm 0.42$ & $6.94 \pm 0.28$ & 79.20 & 89.58 & 0.60 & 0.68 \\
\hline $\mathbf{2 0}$ & $6.85 \pm 0.61$ & $7.91 \pm 0.52$ & 87.20 & 120.60 & 0.66 & 0.91 \\
\hline $\mathbf{4 0}$ & $7.29^{\mathrm{b}} \pm 0.49$ & $8.95^{\mathrm{a}} \pm 0.41$ & 101.28 & 153.90 & 0.77 & 1.16 \\
\hline $\mathbf{6 0}$ & $7.93^{\mathrm{b}} \pm 0.65$ & $9.40^{\mathrm{a}} \pm 0.43$ & 121.76 & 168.30 & 0.92 & 1.27 \\
\hline $\begin{array}{l}\text { Overall mean } \\
\mathbf{\pm S . E}\end{array}$ & $7.17^{\mathrm{b}} \pm 0.53$ & $8.30^{\mathrm{a}} \pm 0.41$ & 97.36 & 133.10 & 0.73 & 1.01 \\
\hline
\end{tabular}

Milk sold@ Rs 32/kg,cost of concentrate=Rs 18/kg, cost of green fodder =Rs 2/kg, cost of paddy straw=Rs3/kg, cost of azolla $=\mathrm{Rs} 1 / \mathrm{kg}$ 
Table.4 Effect of azolla supplementation on milk composition (\%) of crossbred HF cows

\begin{tabular}{|c|c|c|c|c|c|c|c|c|c|}
\hline Days & \multicolumn{2}{|c|}{ Milk fat(\%) } & \multicolumn{2}{c|}{ Milk Protein (\%) } & \multicolumn{2}{c|}{ Milk Lactose (\%) } & \multicolumn{2}{c|}{ Milk SNF (\%) } \\
\hline & Control & Treatment & Control & Treatment & Control & Treatment & Control & Treatment \\
\hline $\mathbf{0}$ & $3.79 \pm 0.15$ & $3.86 \pm 0.14$ & $3.62 \pm 0.12$ & $3.57 \pm 0.12$ & $4.39 \pm 0.11$ & $4.48 \pm 0.15$ & $8.53 \pm 0.19$ & $8.49 \pm 0.28$ \\
\hline $\mathbf{2 0}$ & $3.73 \pm 0.15$ & $3.85 \pm 0.16$ & $3.67 \pm 0.10$ & $3.66 \pm 0.08$ & $4.38 \pm 0.12$ & $4.43 \pm 0.13$ & $8.54 \pm 0.18$ & $8.61 \pm 0.20$ \\
\hline $\mathbf{4 0}$ & $3.76 \pm 0.16$ & $3.84 \pm 0.13$ & $3.73 \pm 0.15$ & $3.68 \pm 0.07$ & $4.40 \pm 0.12$ & $4.43 \pm 0.14$ & $8.64 \pm 0.19$ & $8.65 \pm 0.21$ \\
\hline $\mathbf{6 0}$ & $3.74 \pm 0.13$ & $3.92 \pm 0.15$ & $3.71 \pm 0.12$ & $3.79 \pm 0.07$ & $4.38 \pm 0.07$ & $4.45 \pm 0.16$ & $8.59 \pm 0.14$ & $8.75 \pm 0.18$ \\
\hline $\begin{array}{c}\text { Overall } \\
\text { mean } \mathbf{+ S . E}\end{array}$ & $3.87 \pm 0.15$ & $3.87 \pm 0.14$ & $3.68 \pm 0.12$ & $3.68 \pm 0.09$ & $4.39 \pm 0.11$ & $4.43 \pm 0.15$ & $8.58 \pm 0.18$ & $8.63 \pm 0.21$ \\
\hline
\end{tabular}

Table.5 Effect of azolla supplementation on milk composition ( $\mathrm{kg} /$ day) of crossbred HF cows

\begin{tabular}{|l|l|l|l|l|l|l|l|l|}
\hline Days & \multicolumn{2}{|c|}{ Milk fat(kg/d) } & \multicolumn{2}{c|}{ Milk Protein (kg/d) } & \multicolumn{2}{c|}{ Milk Lactose (kg/d) } & \multicolumn{2}{c|}{ Milk SNF (kg/d) } \\
\hline & Control & Treatment & Control & Treatment & Control & Treatment & Control & Treatment \\
\hline $\mathbf{0}$ & $0.25 \pm 0.02$ & $0.27 \pm 0.02$ & $0.24 \pm 0.02$ & $0.25 \pm 0.02$ & $0.30 \pm 0.03$ & $0.30 \pm 0.02$ & $0.57 \pm 0.07$ & $0.59 \pm 0.03$ \\
\hline $\mathbf{2 0}$ & $0.26 \pm 0.02$ & $0.31 \pm 0.02$ & $0.25 \pm 0.02$ & $0.29 \pm 0.02$ & $0.31 \pm 0.03$ & $0.35 \pm 0.02$ & $0.59 \pm 0.07$ & $0.68 \pm 0.04$ \\
\hline $\mathbf{4 0}$ & $0.28^{\mathrm{b}} \pm 0.02$ & $0.35^{\mathrm{a}} \pm 0.02$ & $0.27^{\mathrm{b}} \pm 0.02$ & $0.33^{\mathrm{a}} \pm 0.02$ & $0.33 \pm 0.04$ & $0.39 \pm 0.02$ & $0.64 \pm 0,07$ & $0.77 \pm 0.07$ \\
\hline $\mathbf{6 0}$ & $0.31^{\mathrm{b}} \pm 0.02$ & $0.37^{\mathrm{a}} \pm 0.02$ & $0.30 \pm 0.02$ & $0.35 \pm 0.04$ & $0.36 \pm 0.04$ & $0.41 \pm 0.04$ & $0.70 \pm 0.08$ & $0.79 \pm 0.05$ \\
\hline $\begin{array}{l}\text { Overall } \\
\text { mean } \mathbf{+ S . E}\end{array}$ & $0.28^{\mathrm{b}} \pm 0.01$ & $0.33^{\mathrm{a}} \pm 0.02$ & $0.26 \pm 0.01$ & $0.30 \pm 0.02$ & $0.33 \pm 0.01$ & $0.36 \pm 0.02$ & $0.62 \pm 0.04$ & $0.71 \pm 0.05$ \\
\hline
\end{tabular}

\section{Effect of azolla on economics}

Azolla incurred only one-time cost of permanent structure and thus involved nominal recurring expenses and the cost of Azolla production was less than one rupees per $\mathrm{kg}$.It has been found that average net returns (Rs 133.10) and benefit cost ratio(B: $\mathrm{C}$ ratio; 1.01) were higher in treatment group. The treatment group incurred 36.71 and 38.36 percent increase in net returns and $\mathrm{B}: \mathrm{C}$ ratio over control. It is attributed to low cost of cultivation involved in the production of azolla and higher milk yield in treatment group. Mathur et al., 2013 also reported low cost of cultivation involved in azolla production as compared to milk yield obtained.

The present study concluded that azolla supplementation is monetary beneficial for crossbred HF cows as evident by increased milk yield, milk fat yield and highest $\mathrm{B}: \mathrm{C}$ ratio.

\section{References}

Alalade, O.A and Lyayi, E.A (2006).Chemical composition and the feeding value of (azollapinnata) meal for egg-type chicks, Int. J. Poult. Sci. 5 (2): 137-141.

Alcantara, P.F. and Querubin, L.J., (1985). Feeding value of azolla meal for poultry.Philippine J. Vet. Anim. Sci., 11:1-8.

Alvaro OcampoDurán, (1994). Raw palm oil as the energy source in pig fattening diets and Azollafiliculoides as a substitute for soya bean meal.Livest.Res. Rural Dev. 6 (1).

Ambade R B, Jadhav S N and Phalke N B (2010) Impact of azolla as a protein supplement and its Influence on feed 
utilization in livestock. Livestock line. 4(4): 21-23.

Association of Official Analytical Chemistry Official Methods of Analysis. $18^{\text {th }}$ Edition, AOAC Washington, DC, 2005.6.

Basak B, Pramanik AH, Rahman MS, Tarafdar SU, Roy BC (2002) Azolla (Azollapinnata) as a feed ingredient in broiler ration.Inj J PoultSci 1(3):2934.

Chatterjee1, A., Sharma, Puneet., Ghosh,M.K., Mandal, M. and Roy, P.K. 2013. Utilization of Azolla Microphylla as Feed Supplement for Crossbred Cattle .International Journal of Agriculture and Food Science Technology.4 (3) : 207-214.

GouriMahadevappa D, SanganalJagadeesh S, Gopinath CR, and Kalibavi CM (2012) Importance of azolla as a sustainable feed for livestock and poultry. Agric Review. 33(2):93-103.

Gowda NKS, Manegar A, Verma S, Valleesha NC, Maya G, Pal DT, Suresh KP (2015) Azolla (Azollapinnata) as a Green Feed Supplement for Dairy Cattle-An On Farm Study. AnimNutr Feed Tech: 15(2): 283-287.

Kamalasanana P, Premalatha, S and Rajamony, S $\quad$ (2002).Azolla-A sustainable feed substitute for livestock.Leisa India, March,2002, pp. 15-17.

Mahadevappa D. Gouri, Jagadeesh S. Sanganal, C.R. Gopinath and C.M. Kalibavi. 2002. Importance of aollaas a sustainable feed for livestock and poultry - a review

Mathur, G N,. Sharma R. and Choudhary, P. C. J. 2013.Use of Azolla (Azollapinnata) as Cattle Feed Supplement KrishiVigyan 2013, 2(1) : 73-75

RawatNidhi, Kumari K, Singh F, Gilhare VR (2015). Effect of Azollasupplemented feeding on milk production of cattle and production performance of broilers.Applied Biological Research. 17 (2): (214218).

Senthilkumar ,S. and Manivannan, C. 2016.Adoption of azolla cultivation technology in the farmers field :an analysis. International Journal of Science, Environment and Technology5(5): $3081-3087$

Singh, B., Meena, G.S, Meena, K.C., Meena, R.K., Singh B. andIndoria ,D.2017. Effect of a Wonder Herb Azolla on Buffaloes Milk Yield .International Journal of Current Microbiology and Applied Sciences: 6( 11) : 1059-1066.

Snedecor GW, Cochran WG (1989) Statistical methods, 8th edn. Iowa State University Press, Ames Iowa

Van Soest PJ, Robertson JB, LewisBA. Methods for dietary fibre, neutral detergent fibre and non-starch polysaccharides in relation to animal nutrition. Symposium: carbohydrate methodology, metabolism and nutritional implications in dairy cattle. JDairy Sci.1991; 74:3583-97.

\section{How to cite this article:}

Manpreet Kour, Nazam Khan, Rajeev Singh, Vikas Mahajan, Suraj A. Amrutkar and Dhirendra Kumar. 2020. Effect of Azolla (Azolla pinnata) Supplementation on Milk Yield, Composition and Economics in Crossbred HF Cows. Int.J.Curr.Microbiol.App.Sci. 9(10): 2661-2666. doi: https://doi.org/10.20546/ijcmas.2020.910.320 